\title{
Infinite Movement: Robert Browning and the Dramatic Travelogue
}

Gregory Tate 
The speaker of Robert Browning's "Clive" (1880) is an old soldier who served with Robert

Clive in India before witnessing the general's decline into disgrace and suicide. Thinking over his memories of Clive, the speaker figures the act of remembering as a recapitulation of the military marches of his youth:

thought grows busy, thrids each pathway of old years,

Notes this forthright, that meander, till the long-past life appears

Like an outspread map of country plodded through, each mile and rood,

Once, and well remembered still. (11. 11-14) ${ }^{1}$

The speaker identifies his mental process as a form of motion: his thoughts journey down the pathways of memory, retracing the footsteps of his plodding through India. He also presents thought as visual, likening memory to the outspreading of a map, a chart which regulates the movements of the mind. This visual conception of thinking is present too in the speaker's account of the ailing Clive, whom he recalls staring at a table-top "as though / Tracing, in the stains and streaks there, thoughts encrusted long ago" (11. 87-8). The difference between the two men's thoughts is that while the speaker's memories are "busy", Clive's opium-addled brain is trapped in pathological stasis: his brooding thoughts are "encrusted", stuck in one place. The speaker's more dynamic thought processes encapsulate two recurring features of Browning's representation of psychology in his dramatic monologues: the conviction that thought is (or should be) active and mobile, and the use of motifs of travel to evoke this mobility.

In this poem the speaker's travels are in his head: he remains physically in the same place while taking a mental journey into the foreign country of his past. More commonly, though, Browning's monologues are voiced by speakers who are physically on the move, travelling from place to place just as their minds shift from thought to thought. This essay will argue that Browning's travel monologues (or dramatic travelogues) utilize the unfolding events of a journey to enact the relentless mutability of their speakers' minds. These poems can be read to some extent as travel narratives, but the geographical and psychological 
voyages they recount rarely reach a definite conclusion: even as they are moving, the speakers of these poems seem to be going nowhere fast. Yopie Prins, discussing the importance of motion to the forms and narratives of Browning's writing, has noted that "the rapid acceleration of Browning's poetry is structured by interruption and disruption rather than continuous flow." "2 The journeys in Browning's monologues, then, can be seen both as examinations of the movements of thought and travel and as reflections on the difficulty of fashioning a straightforward narrative from the accelerations and interruptions of verse form. This overlapping of psychological and formal concerns is intrinsic to the dramatic monologue, a genre which seeks to merge the lyric articulation of subjectivity with the presentation of a contextual narrative. Monique R. Morgan has argued that it is the narrative movement of the dramatic monologue which differentiates the form from the stasis of lyric, claiming that, while lyric verse seeks to represent "absolute simultaneity in a suspended moment", the dramatic monologue "gives the [speaker's] discourse the developing temporality of narrative, rather than aspiring to the seemingly simultaneous meaning of lyric."3 I will argue, however, that Browning's monologues of inexorable physical and psychological travel demonstrate just this aspiration to the "suspended" condition of lyric simultaneity. His speakers typically hope for an end to motion, to thought, and to narrative.

This aspiration remains, more often than not, unrealized, because Browning's monologues persistently reiterate a conception of psychology as flux and motion, in which any pauses are temporary. A dramatic monologue, for Browning, comprises the expression of the changes and movements of its speaker's mind as that mind reacts to external events (the response of an auditor, for example, or the incidents of a journey). This psychological stance, which bears comparison to the nineteenth-century associationist theories of psychology that identified the mind as a series of transient mental states founded on the data of sensory experience, was noted by some Victorian critics. ${ }^{4}$ Reviewing Red Cotton Night-Cap Country 
in the Journal of Mental Science in 1874, J. H. Balfour Browne hailed Browning as "an anatomist of the very inmost spirit of humanity, because he understands" that thoughts "are modified by the circumstances which constitute a man's environment in time or space". 5 The thoughts of Browning's travelling speakers are never at rest, because their changing minds are modified by their environments in an unending process of transformation.

The link between environment and subjectivity examined in Browning's monologues is a pervasive concern of Victorian writing on travel; James Buzard has argued that travel writers use their accounts of their journeys to fashion "lasting conceptions [...] about themselves and the societies they inhabit and tour-images of self and setting reciprocally reinforcing one another."6 Browning's monologues capture just this reciprocal connection between "self" and "setting", but his emphasis on the mutability of travel and of thought questions whether the self-conceptions formed through journeying (or through experience more generally) can ever be "lasting”. Recent scholarship on Victorian travel writing has tended to pass over the specific contribution that Browning, arguably the most peripatetic of Victorian poets, made to nineteenth-century representations of travel. However, Christopher M. Keirstead, one of the few critics to consider Browning's travel writing in detail, has discussed the relation between traveller and environment in terms of genre, suggesting that Browning's poetry evinces "an unresolvable tension between the self-oriented mode of lyric", which figures "travel as a kind of self-enrichment", and the dramatic "aim of constructing that self through its engagement with the outside world". ${ }^{7}$ Browning's travelogues present dramatic narratives that chart the engagement of the self with the world, but they are voiced by speakers who long to escape narrative and to realize a lyric autonomy. This longing to bring narrative to an end draws attention to the generic strategies not just of the dramatic monologue but also of travel writing. Barbara Korte has noted that this writing deploys "lines of development $[\ldots]$ and other structural elements" that "were not part of the original 
experience of the journey itself. The experience of travel is translated, in the text, into a travel plot." ${ }^{\prime 8}$ Browning's monologues constitute a self-conscious interrogation of this process of translation, as his speakers strive to reach the end of their journeys, only to find that their travels resist plotting and narrative resolution.

Browning's interest in the narrative and psychological ramifications of travel was informed by a wealth of personal experience: he travelled in Europe throughout his life, and although he and Elizabeth Barrett Browning (EBB) settled in Florence after their marriage, they regularly journeyed around Italy as well as to Paris and London, EBB admitting in 1851 that "we cant $\left[\right.$ sic] give up our travelling vocation". ${ }^{9}$ Before an 1844 trip to Italy, Browning even considered publishing a record of his travels, telling Frederick Oldfield Ward, the acting editor of Hood's Magazine, that "I will try—try, really,- to write you some letters from the sea-way to Naples-and then you may advertise after what fashion you will". ${ }^{10}$ Nothing came of this plan, but Browning's commitment to incorporating his "vocation" for travel into his writing is apparent in the number and variety of travel scenarios presented in his monologues. This essay will focus on three such scenarios: the tourist jaunt of "The Englishman in Italy" (first published as "England in Italy" in 1845), the chivalric quest of " "Childe Roland to the Dark Tower Came"”, and the horseback excursion of "The Last Ride Together" (both published in Men and Women in 1855). These poems seem, on the surface, to recount three very different travel narratives, but they share an underlying structure, in which a journey that appears to have a definite and delimited purpose is instead revealed to be an interminable process of physical movement and psychological change with no fixed end. In each poem the speaker's travels reflect Browning's views on the mutability of thought and on the narrative complexities of the dramatic monologue.

The notion of mental mutability was central to Browning's understanding of the monologue form, and, both within his poems and in his comments on his work, he 
consistently linked these psychological and formal issues to concepts of travel. In 1855 John Ruskin wrote to Browning, lamenting the obscurities of Men and Women in terms that fired the poet's imagination: "You are worse than the worst Alpine glacier I ever crossed. Bright, \& deep enough truly, but so full of clefts that half the journey has to be done with ladder and hatchet."11 Browning, in his reply, reworks Ruskin's disapproving account of this arduous journey into a celebration of the dynamism of his poetry: "You ought, I think, to keep pace with the thought tripping from ledge to ledge of my 'glaciers,' as you call them; not stand poking your alpenstock into the holes, and demonstrating that no foot could have stood there;- - suppose it sprang over there?"12 While Ruskin makes painstaking progress with "ladder and hatchet", exhaustively going over each word and line of Browning's poetry, the poet himself presents verse as the freewheeling "tripping" of "thought" and "foot", a mental (and metrical) motion which, as Herbert F. Tucker notes, "reconceive[s] poetic meaning as a process instead of an entity". ${ }^{13}$ More specifically, Browning's formulation reconceives poetic meaning as a process of thinking, stressing that the monologues of Men and Women are driven by the movements of "thought", with which the reader must "keep pace". For Browning, thought and the monologue form are inherently mobile, and he often employs the physical and mental transformations of the traveller as figures for this mobility.

Browning's letter to Ruskin revels in the movements of travel, but the poet was also alert to the psychological significance of the frustrations and difficulties involved in travelling. In his efforts at flattery in his first letter to EBB, for instance, he relates how he once missed an opportunity to meet her:

I feel as at some untoward passage in my travels - as if I had been close, so close, to some world's-wonder in chapel or crypt, .. only a screen to push and I might have entered-but there was some slight .. so it now seems .. slight and just-sufficient bar to admission, and the half-opened door shut, and I went home my thousands of miles, and the sight was never to be! ${ }^{14}$ 
Browning casts himself as a sightseer and his correspondent as a tourist destination, a "world's-wonder" that he had voyaged "thousands of miles" to see. This physical movement, however, is ultimately for nothing: while Browning implies that this sight would have had a transformative effect on the traveller, this passage of his journey is "untoward" and fails to arrive at its intended goal. Destinations, Browning points out, can easily be missed, a contingency that threatens to rob travel of psychological and narrative resolution.

In another letter written three months later, in April 1845, Browning pushes this sceptical assessment of travel even further, rejecting the notion that the experiences of travel have any influence on the workings of the mind. He assures EBB that

all you gain by travel is the discovery that you have gained nothing, and have done rightly in trusting to your innate ideas - or not rightly in distrusting them, as the case may be: you get, too, a little .. perhaps a considerable, good, in finding the world's accepted moulds every where, into which you may run \& fix your own fused metal,but not a grain Troy-weight do you get of new gold, silver or brass. ${ }^{15}$

Browning views the self here as an essentially static entity, founded on unchanging and "innate ideas" and fitted to the "accepted moulds" which are identifiable throughout the world. His downplaying of the gains of travel might have been motivated by a wish to reassure EBB that she was not missing much through her confinement as an invalid, but it also points to an important aspect of his thinking about psychology: his belief that, although the earthly mind is shaped by the fluctuations of circumstance, there remains another (spiritual) element of personal identity that transcends such conditions. In her reply to his letter, however, EBB takes issue with Browning's dismissal of travel, suggesting that it is impossible to "separate the results in you from the external influences at work around you". "Whatever acts upon you," she tells him, "becomes you .. \& whatever you love or hate, whatever charms you or is scorned by you, acts on you \& becomes you". ${ }^{16}$ The self, EBB asserts, is transformed by experience, and, despite Browning's demurral in his letter, his 
dramatic travelogues present a similar account of the relation between "external influences" and the internal movements of the mind.

This relation is a structuring concern of "The Englishman in Italy". The monologue is spoken by an English tourist staying near the Plain of Sorrento (as Browning did in 1844), but, for a poem about travelling, it features surprisingly little motion: only the second of its three episodes, in which the speaker ascends a local mountain to obtain a view of the plain and the sea, recounts a physical journey. The rest of the monologue attends to another aspect of the culture and industry of tourism as it was developing in the mid-nineteenth century: the sedentary consumption of things and experiences. This consumption is, in Browning's poem, both culinary and cultural: the first part details the plentiful food and drink on offer in Italy, while at the poem's close the speaker looks forward to watching a religious procession at the local Catholic church. In the words of Robert Viscusi, "the poem is, to put it bluntly, an advertisement" for Italian tourism: "its dialect is precisely the mouth-watering diction of the advertisement". ${ }^{17}$ This dialect consists of long lists of consumables, things to be eaten and things to be seen. The speaker begins by lingering lovingly over the "pomegranates", "figs", "shrimps", "snails", and "wine" that he has sampled (1l. 23, 46, 64, 90, 110), and in his monologue's closing lines he anticipates the "red and blue papers", "long tapers", and "great bonfires" that will be used to mark the procession (11. 258, 260, 278). ${ }^{18}$

His habits of consumption also impinge on his representation of his thought processes. In the opening lines of the poem he resolves to amuse Fortù, the Italian girl to whom he is addressing his words,

With telling my memories over

As you tell your beads;

All the Plain saw me gather, I garland

-Flowers prove they, or weeds. (11. 9-12)

The workings of memory are imagined in "Clive" as physical motion, a re-enactment of the speaker's past movements. Here, conversely, the tourist identifies memory as an accretion of 
things, which can be garlanded like flowers or told like beads on a rosary. This anticipates his account of his travels as an accumulation of sensory experiences, and his monologue's recurring focus on sensory data is in keeping with the widespread privileging of subjective sensation in nineteenth-century lyric verse. Viscusi reads "The Englishman in Italy" as an example of Victorian poetry's "obsessive attention to the data of sense-perception," its conviction that the senses are the "channels through which what is in the human situation most profound, most wonderful, most true, communicates itself to the human mind" (Viscusi, p. 14; author's italics). This only tells half the story, because Browning and other Victorian poets are often thoroughly sceptical about the capacity of the senses to convey a meaningful account of "the human situation"; this scepticism towards subjective experience and perception is a central feature of Browning's dramatic monologues. Nonetheless, the opening lines of "The Englishman in Italy" present a speaker whose mind and self-conception are shaped overwhelmingly by his sensory experiences of the external world.

The speaker's status as an inactive consumer means that the first part of the poem is characterized by a sort of psychological and narrative inertia: neither the speaker nor his monologue appear to be moving forward. This is reinforced by the poem's form, as the alternating unrhymed lines and the irregular rhythm (with five metrical stresses spread over two lines and a varying number of syllables) disrupt the flow of the verse. The awkwardness of reading this poem supports EBB's observation to Browning that, in his poetry, "the uncertainty of rhythm throws the reader's mind off the rail .. \& interrupts his progress with you and your influence with him."19 In 1872 Browning amended "The Englishman in Italy" in an effort to give the reader's mind a less gruelling metrical journey, amalgamating its long and short lines into single lines that rhymed in couplets. The revised versification is smoother, but in the last reprinting of "The Englishman in Italy" in Browning's lifetime he reverted to the original lineation, suggesting that the unevenness of the poem's formal movement is 
integral to its meaning. Despite her concern about the interrupted progression of Browning's verse, EBB praised "the rushing \& hurrying life of the descriptions" in "The Englishman in Italy", asserting that "for giving the sense of Italy, it is worth a whole library of travel-books" (Poems, 2:343-4; author's italics). In EBB's terms, then, the form of this monologue could be characterized by motion without direction, a "rushing and hurrying" movement that makes only uncertain progress towards any destination. A similar dynamic is traceable in the travel narrative of the poem's second part and in the speaker's psychological responses to his journeyings.

This travel narrative, in which the speaker recalls his excursion of the previous day to a nearby mountain, brings with it a significant alteration in tone that is particularly evident when he reaches the mountain's summit:

And God's own profound

Was above me, and round me the mountains, And under, the sea, And with me, my heart to bear witness What was and shall be!

Oh heaven, and the terrible crystal! (11. 172-7)

The speaker's language becomes a portentous mix of religious awe and Romantic subjectivism, as he connects his own "heart" to the mountainous scenery surrounding him. He presents a Wordsworthian conception of travel in which his journey ends with a vision of the natural sublime which in turn triggers introspective insight into the human heart. His ascent and his narrative seem to culminate in this moment of lyric self-revelation, but there are unresolved tensions in his recollection of his sublime insight, both because his vague Romantic diction ("what was and shall be") feels out of place after the language of touristic excess that pervaded the first part of the poem, and because this is a past-tense and confessedly retrospective account in which the speaker is superimposing a conclusive narrative structure onto his experiences of travel. 
This evocation of the Romantic sublime is simultaneously the apotheosis of tourism, as the speaker offers his overenthusiastic review not just of his trip but also, and more importantly, of its effect on his subjectivity. But the narrative resolution which appears to go along with this evocation of the tourist sublime is subverted in the lines which follow, as the speaker concedes that his journey is not yet finished:

Oh, those mountains, their infinite movement!

Still moving with you-

For ever some new head and breast of them

Thrusts into view

To observe the intruder-you see it

If quickly you turn

And, before they escape you, surprise them. (11. 181-7)

There is a renewed sense of motion here after the epiphanic tableau of lines 172-7: the Englishman can only keep the mountains in view by executing a quick "turn", comparable, perhaps, to the turn from one line of verse (the word derives from the Latin vertere, "to turn") to the next. The view from the summit appeared to mark the end of the speaker's journey, as he recognized an unchanging truth about his own identity. His insight is revealed to be provisional, however, because he, the mountains, and the monologue he is speaking are all "still moving". This movement, the speaker says, is "infinite": there is no end to the mutability of his circumstances or of his thoughts.

Disconcerted by this discovery, the speaker fantasizes about another tourist excursion, one that will enable him to reach some sort of psychological equilibrium. He imagines sailing to the islands off the coast, home of the mythological sirens, where he will

Reach land and explore

On the largest, the strange square black turret

With never a door-

Just a loop that admits the quick lizards;

- To stand there and hear

The birds' quiet singing, that tells us

What life is, so clear;

The secret they sang to Ulysses,

When ages ago

He heard and he knew this life's secret 
I hear and I know! (11. 218-28)

As in his Romantic vision on the mountain, the speaker asserts that sensory experience, in this case the singing of the birds rather than the view, yields "secret" knowledge. Again, though, the insight that the speaker purportedly gains from his senses and his travels is tenuous, both because he remains suspiciously silent about the content of his secret and because this journey takes place solely within his mind. These lines, it seems, present the wish-fulfilment of a tourist who longs for the self-knowledge that has so far escaped him on his travels. If the "black turret" represents the final destination of the speaker's psychological wanderings, it is significant that it has "never a door": like Browning missing his chance to meet $\mathrm{EBB}$, the speaker is denied access to the goal he thinks he is moving towards. Daniel Karlin has linked this turret to the titular structure in "“Childe Roland to the Dark Tower Came", arguing that, although "The Englishman in Italy" "has a quite false reputation as a travelogue, amiable and diffuse", it displays "a highly ordered narrative structure", founded, like that of the later monologue, on a "quest or journey" which is revealed, in the end, "to be an ambivalent affair". ${ }^{20}$ It could be argued, however, that "The Englishman in Italy" is a travelogue precisely because of the ambiguity of its journey narrative. This dramatic travelogue suggests that the movements of travel, like the processes of thought and the narrative dynamics of the monologue form, are haphazard and difficult to pin down, and might never reach a definitive end.

The speaker of "“Childe Roland to the Dark Tower Came"” seems to have a firm idea of where he is going, and, eventually, he gets there:

What in the midst lay but the Tower itself?

The round squat turret, blind as the fool's heart, Built of brown stone, without a counterpart

In the whole world. (11. 181-4)

Roland depicts the dark tower in terms that suggest a tourist sight: it is the sole destination of his journeying, "without a counterpart / In the whole world", a must-see. Yet the tower itself 
is "blind", presumably windowless and doorless, and, like the doorless turret on the tourist's island, it remains an impenetrable mystery. Its blindness is transferred to Roland: although he has apparently reached his destination, the (possibly) rhetorical question that he asks in line 181 indicates that he is not sure what he is looking at. While the poem's title describes the conclusion of a voyage, the journey that unfolds within its stanzas is fragmented and illogical, and this monologue lays bare the ambiguities and complexities of travel hinted at in "The Englishman in Italy". It also constitutes a critique of the idea that writing can impose order on the mutable experiences of the travelling self.

Throughout the monologue, the incoherence of Roland's experiences is reflected in the confusion of his thoughts. Browning claimed that this poem "came upon me as a kind of dream" (Poems, 3:240), and Roland's narrative and his thinking are both marked by dreamlike distortions. This is evident from the poem's opening line: "My first thought was, he lied in every word" (1. 1). Roland thinks that the "hoary cripple" (1. 2) who directs him to the tower is a liar, but he either changes his mind or acts without reference to his thoughts, because he follows the cripple's directions anyway, an apt beginning to a poem characterized throughout by contradiction and discontinuity:

Yet acquiescingly

I did turn as he pointed; neither pride

Nor hope rekindling at the end descried,

So much as gladness that some end should be.

For, what with my whole world-wide wandering, What with my search drawn out thro' years, my hope

Dwindled into a ghost not fit to cope

With that obstreperous joy success would bring. (11. 15-22)

Roland's “wandering” through space ("whole world-wide”) and time (“drawn out thro' years") has so far been endless, and it has driven him to the point where he no longer cares about the goal of his quest: he just desires "some end", any end. The confusion of his thoughts and of his attenuated emotions suggests that, tired of thinking and feeling, he is 
likewise willing to accept any sort of resolution to the interminable fluctuations of his mental processes.

It is not surprising that those processes are exhausted and incoherent, because they are forced, as Roland travels, to keep pace with sensory experiences that shift and change with baffling rapidity. This monologue unflinchingly exposes both the inherent plotlessness of travel and the unstoppable mutability of thinking, as it enacts a series of sudden leaps from one location or thought to another, a series that defies narrative ordering. This is apparent as soon as Roland follows the cripple's directions:

For mark! no sooner was I fairly found Pledged to the plain, after a pace or two, Than pausing to throw backward a last view To the safe road, 'twas gone! grey plain all round! Nothing but plain to the horizon's bound. I might go on; nought else remained to do.

So on I went. I think I never saw

Such starved ignoble nature; nothing throve. (11. 49-56)

These lines suggest that Roland's mind is permanently in motion because his thoughts are shaped by his changing circumstances. Faced with the bewildering transformation of his surroundings in the first stanza, Roland has "nought else" to do but keep moving (and thinking). Robert Langbaum argues in The Poetry of Experience that Childe Roland's monologue, like all dramatic monologues, is a poem concerned with a subjective "experience" rather than an objective "situation": the monologue's "forward movement is automatic, magical; [...] it marks no sort of progress. When the knight finally achieves the Dark Tower, it is not because the forward movement has brought him there but because of a transformation of consciousness. ${ }^{, 21}$ This transformation is not, however, the sort of conclusive self-revelation imagined by the speaker of "The Englishman in Italy", but just one of an interminable series of psychological fluctuations. Moreover, Roland's mental experience cannot be separated from his physical situation as easily as Langbaum implies; 
instead, the two are inescapably intertwined. The processes of Roland's mind are perplexed by the mutability of the surrounding landscape, a mutability that also subverts the logical progression through space and time on which travel narratives, and narratives in general, usually insist.

This sense of narrative dislocation intensifies as Roland's quest and monologue "go on”. After two stanzas (11. 145-56) in which Roland straightforwardly delineates the changing terrain through which he passes, the fragile thread of his journey narrative suddenly unravels:

And just as far as ever from the end!

Nought in the distance but the evening, nought

To point my footstep further! At the thought, A great black bird, Apollyon's bosom-friend,

Sailed past, nor beat his wide wing dragon-penned

That brushed my cap-perchance the guide I sought.

For looking up, aware I somehow grew,

'Spite of the dusk, the plain had given place

All round to mountains - with such name to grace

Mere ugly heights and heaps now stol'n in view.

How thus they had surprised me,- - solve it, you!

How to get from them was no plainer case. (11. 157-68)

Despite his movement over the course of the poem, Roland has not progressed: he is "just as far as ever from the end". This alarming lack of physical and psychological progress is paralleled in the structure of the poem's stanzas: the abbaab rhyme scheme reads, on one level, as an extension of the abba stanza of Tennyson's In Memoriam, a form which enacts cyclical motion and the halting of progress. This is reinforced in the first stanza by the acoustic repetition of the supposedly conclusive word "end" and by the rhyming of "thought" with "nought" and the provisional "sought". Although the shift, across each stanza, from the opening $a$ rhyme to the terminal $b$ rhyme introduces an element of formal progression, it is the same sort of faltering and discontinuous progression that marks Roland's journey throughout the poem. In these stanzas, Roland is forced to move as the landscape transforms for a second time, but while he perceives this transformation, he is unsure of what to make of 
it and baffled about how to move forward. The inexorable but directionless motion of the stanzas' form and narrative can be read as anticipating what Graham Huggan has identified as the peculiarly twentieth-century genre of "uncanny travel writing", in which travel becomes an index of psychological trauma, as the alienated consciousness of the traveller wanders "through a half-lit Gothic landscape of ephemeral images, macabre dream-visions, eerily duplicated resemblances, and disquieting shadow selves." 22 For Browning, travel is uncanny because it reveals the ephemerality not just of images and experiences but of the mind, as the mutability of Roland's surroundings and of his mental processes traps him in an endless cycle of physical and psychological changes.

The psychological aspect of these changes is examined in this monologue, as in "Clive" and "The Englishman in Italy", through reflection on the processes of memory, which promise to affirm the identity of the mind across time but which also act as a check on the forward progress of the self. Roland, appalled by the futility of his quest, looks to his memories for solace:

I shut my eyes and turned them on my heart. As a man calls for wine before he fights,

I asked one draught of earlier, happier sights

Ere fitly I could hope to play my part.

Think first, fight afterwards - the soldier's art:

One taste of the old times sets all to rights! (11. 85-90)

Roland at first locates his memories in his heart, but line 89 (“Think first, fight afterwards") suggests that he is concerned with cognition rather than emotion; he hopes that his recollections of the past can counter the gloom of his present thoughts, which are shaped in their anxiety by his terrifying experiences. The wording of the line, however, recalls Roland's confused and irrelevant "first thought" in the first line of the monologue, and this echo suggests that memory might be just as unreliable as other types of thinking.

This is confirmed as Roland, calling up fond recollections of his fellow knight Giles, finds his "draught" of memory turning sour: 
Good—but the scene shifts—faugh! what hangman's hands

Pin to his breast a parchment? his own bands

Read it. Poor traitor, spit upon and curst!

Better this present than a past like that-

Back therefore to my darkening path again.

No sound, no sight as far as eye could strain.

Will the night send a howlet or a bat?

I asked: when something on the dismal flat

Came to arrest my thoughts and change their train. (11. 100-108)

Throughout these stanzas thought is described in visual terms, as a "scene" observed with the "eyes", but it is also represented as motion: the scene shifts of its own accord, and Roland is powerless to stop his happy memories being pushed aside by horrific ones. Something similar happens when he resumes thinking about the present: his thoughts move along smoothly enough while there is "no sound, no sight" to interrupt them, but as soon as a new sensation appears they are immediately arrested and changed. Suzanne Bailey has argued that such shifts in attention are characteristic of Browning's handling of narrative: "One could paraphrase Browning's narrative strategy in terms like these: 'Look at this. Think of this. Now look at this.' The pattern is one of visual montage rather than of logical development" (Bailey, p. 93). This is true both of Roland's narrative, which shifts erratically from one scene to another, and of his mental processes, which, moving rapidly between conflicting thoughts and memories, seem to have no recourse to "logical development" or personal agency.

The workings of Roland's mind move in tandem with his physical mobility: his precarious train of thought is derailed both by painful memories and by the disconcerting experiences of his bewildering journey. In other monologues, though, Browning presents the physical motion of travel as a means of liberating the self from the perplexing mutability of thought. The speaker of "'How They Brought the Good News from Ghent to Aix"” (1845), for instance, recalls how he and his companions, riding between the two towns, travelled in silence: "Not a word to each other; we kept the great pace / Neck by neck, stride for stride, never changing our place" (11. 7-8). The speaker evokes a rapid and undeviating motion 
which is speechless and, as becomes clear over the course of the poem, thoughtless. The movement presented in this monologue is predominantly physical: the speaker is concerned with narrating the incidents of his journey rather than recording his subjective responses to them. Significantly, the poem was written at a time when Browning's tourist wanderings had got him thinking about the pleasures of other types of journey: it was composed on a ship off the coast of Africa during his 1844 trip to Italy, when "I had been at sea long enough to appreciate even the fancy of a gallop on a certain good horse 'York,' then in my stable at home". Browning embodied this "fancy" in the poem's famously propulsive anapaestic metre and in his speaker's journey, even though, as he stated forty years later, he was not certain how the speaker would get to where he was going: because Browning "had no map, and wrote swiftly $[\ldots]$ the places mentioned were remembered or guessed at loosely enough" (Poems, 2:239-40).

Despite this want of a map, this poem differs from most of Browning's travelogues in recounting a journey that arrives unequivocally at a final destination. Yopie Prins characterizes this monologue as a "poem in perpetual motion" (Prins, p. 216), but the metrical and geographical motion enacted in its verse is not perpetual: as the poem and its narrative draw to an end, the speaker reaches his destination and then stops. It is only after he has reached Aix on his horse Roland that he starts to pay more attention to his thoughts, as is shown in the shift from the penultimate to the closing stanza: "Till at length into Aix Roland galloped and stood. // And all I remember is, friends flocking round" (11. 54-5). Across the stanza break, the physical motion of the ride is replaced by the speaker's reflections on his memories of that ride, but the bulk of the poem records a journey that is free from the burdens of thinking and that, despite its many dangers and setbacks, ends up in the location promised by the poem's title. The resolution of this journey perhaps gave Browning some 
personal and poetic relief from the contingent and interminable motion usually involved in travelling.

It appears, though, that he never needed more than a temporary respite: "'How They Brought the Good News from Ghent to Aix"' is an atypical travel monologue, and other poems reaffirm Browning's interest in the perpetual physical and psychological motion of travel. A less famous poem about horse-riding, "The Last Ride Together", offers a striking contrast to the ride from Ghent to Aix, because its speaker, a rejected lover who persuades his mistress to join him for a farewell gallop, insistently stresses the link between physical mobility and psychological mutability. The movement of travel enables the speaker to outrun his disappointments:

Then we began to ride. My soul

Smoothed itself out, a long-cramped scroll

Freshening and fluttering in the wind.

Past hopes already lay behind. (11.34-7)

As in "Clive", psychological interiority is figured both as motion ("fluttering in the wind") and as an unfolding text ("a long-cramped scroll"). Unlike "Clive", however, this monologue suggests that the movements of the mind are determined by physical motion: it is the sensation of riding which enables the speaker's psyche to freshen and smooth itself out. The ride in this poem has no destination (the country, region, or terrain through which the couple are riding is never specified) and so the monologue participates in the trend within Victorian travel discourse which posits, in the words of Barbara Korte, that "the fundamental aim of a journey consists in the experience of travel as such, not in reaching a particular destination" (Korte, p. 101). Travel is presented in this monologue not as a journey towards a specific location, but as a psychological necessity: through riding, the speaker spatializes his thought processes and leaves his "past hopes" physically "behind" him.

He seems uninterested, conversely, in what is ahead of him. While Childe Roland and the English tourist are disconcerted to find their seemingly fixed destinations slipping away 
from them, resisting subjective interpretation and narrative closure, this speaker embraces his lack of destination and revels in the psychological freedom of travel:

We rode; it seemed my spirit flew,

Saw other regions, cities new,

As the world rushed by on either side.

I thought, All labour, yet no less

Bear up beneath their unsuccess. (11. 47-51)

In these lines thought and travel move in concert, as the physical experience of riding triggers fresh ideas which offer the speaker consolation. Yet the movements of the speaker's mind also go beyond his immediate circumstances, as his journey exceeds its geographical bounds and he glimpses "other regions, cities new", suggesting that, while his thoughts begin in the sensations of bodily movement, they have the capacity to transcend physical conditions and to exist as unfettered imagination. The speaker's use of words such as "soul" and "spirit" indicates that he, for one, believes there is a spiritual or metaphysical dimension to his journey. But while in the first two lines the speaker is flying high, in the third line it is the outside world which is on the move, and he, from his own point of view, is fixed in one place. Like the subjective perspective of the dramatic monologue form, the rapid motion of travel can limit and even distort perception, and this suggests that the travelling speaker, although moving and changing, might not be progressing.

The speaker is nonetheless convinced that riding grants his psyche freedom of movement. He is more sceptical about the motive force of poetry, which he considers, in one stanza, as a means of making sense of his disappointment:

What does it all mean, poet? well, Your brain's beat into rhythm-you tell What we felt only; you expressed You hold things beautiful the best, And pace them in rhyme so, side by side.

'Tis something, nay 'tis much-but then, Have you yourself what's best for men? Are you-poor, sick, old ere your timeNearer one whit your own sublime Than we who never have turned a rhyme? 
Sing, riding's a joy! For me, I ride. (11. 67-77)

In contrast to the spiritual terms he employs elsewhere, the speaker locates poetry in the "brain", tying the rhythms of verse to the physical sensations of motion he experiences when riding. But he is ambivalent about poetry: on the one hand, he states that the poet can "tell" the subjective sensations and emotions that most people only mutely feel; on the other hand, he doubts whether this capacity can help the poet to reach the "sublime" of self-knowledge. He expresses this ambivalence in terms of movement, articulating the link between form, motion, and psychology which is implicit in other travel monologues. He claims that poems "pace"- a riding term meaning, according to the Oxford English Dictionary, "to put (a horse, etc.) into a controlled, easy gait"-ideas and sensations "side by side": poetry, he suggests, is the organized and purposive development of lines of thinking or feeling. But, as the phrase "turned a rhyme" suggests, verse also involves turning and pausing, and the starting of new lines, both poetic and psychological. Poetic narrative is founded on the rhythmic motion of poetic form, but that motion involves both going forward and turning back. This is evident in the rhyme scheme of "The Last Ride Together", the progress of which is interrupted by the return, at the end of each stanza, to the rhyme of the fifth line.

An equivalent sort of motion, arrested yet unending, forms the basis of the speaker's speculations in the poem's final stanza:

What if Heaven be, that, fair and strong

At life's best, with our eyes upturned

Whither life's flower is first discerned,

We, fixed so, ever should so abide?

What if we still ride on, we two,

With life for ever old yet new,

Changed not in kind but in degree,

The instant made eternity,-

And Heaven just prove that I and she

Ride, ride together, for ever ride? (11. 101-10)

The speaker hopes that he and his lover can "for ever ride": his wish is for an eternal and heavenly journeying that will be a prolongation of the physical motion of riding ("changed 
not in kind but in degree"). But he also hopes to remain eternally the same, "fixed" in motion, a paradoxical state that would elevate the transient moment into an "instant made eternity". Although he is happy to keep moving, the speaker, like Browning's other travellers, also longs to put an end to his psychological fluctuations and sufferings and to conclude his narrative in a lyric moment of stasis and equilibrium. This longing is never straightforwardly realized: the tourist in "The Englishman in Italy" describes a sublime self-revelation that gives way to "infinite movement"; Childe Roland reaches the ambiguous end of his quest only after a lifetime of "world-wide wandering"; and the speaker of "The Last Ride Together" is left wishing, probably hopelessly, for his eternal instant. Browning suggests that neither the mind nor poetry can attain a lyric or heavenly stasis, because the interminable temporal and spatial changes of the self and the world impose an element of narrative that cannot be definitively resolved. Throughout his monologues Browning uses travel as a figure for this unending process of physical and psychological change, and he himself was sanguine about the possibility of remaining, this side of heaven, a perpetual wanderer. Writing to Isabella Blagden after going from Florence to Paris in 1858, EBB recorded how much the Brownings had enjoyed the journey: "I was nearly sorry to arrive, \& Robert suggested the facility of 'travelling on for ever so.",23

\footnotetext{
${ }^{1}$ Line references to "Clive" are from Robert Browning, The Poems, ed. John Pettigrew and Thomas J. Collins, 2 vols. (New Haven: Yale University Press, 1981).

${ }^{2}$ Yopie Prins, "Robert Browning, Transported by Meter", in The Traffic in Poems: Nineteenth-Century Poetry and Transatlantic Exchange, ed. Meredith L. McGill (New Brunswick: Rutgers University Press, 2008), p. 205. ${ }^{3}$ Monique R. Morgan, Narrative Means, Lyric Ends: Temporality in the Nineteenth-Century British Long Poem (Columbus: Ohio State University Press, 2009), pp. 135, 167.

${ }^{4}$ For a consideration of Browning's engagement with nineteenth-century psychological theory, see Gregory Tate, The Poet's Mind: The Psychology of Victorian Poetry 1830-1870 (Oxford: Oxford University Press, 2012). Presenting a different perspective on Browning's conception of mind, Suzanne Bailey has used recent models of cognitive science to argue that the poet's personal "cognitive style" was "characterized by energy, $[. .$. perpetual movement from one thought to the next". Suzanne Bailey, Cognitive Style and Perceptual Difference in Browning's Poetry (London: Routledge, 2010), pp. 42, 90.

${ }^{5}$ J. H. Balfour Browne, review of Red Cotton Night-Cap Country, Journal of Mental Science 20 (1874): 214.

${ }^{6}$ James Buzard, The Beaten Track: European Tourism, Literature, and the Ways to "Culture", 1800-1918 (Oxford: Clarendon Press, 1993), p. 5.

${ }^{7}$ Christopher M. Keirstead, "Stranded at the Border: Browning, France, and the Challenge of Cosmopolitanism in Red Cotton Night-Cap Country", Victorian Poetry 43 (2005): 429.
} 


\footnotetext{
${ }^{8}$ Barbara Korte, English Travel Writing from Pilgrimages to Postcolonial Explorations, trans. Catherine Matthias (Basingstoke: Palgrave, 2000), p. 10; author's italics.

${ }^{9}$ EBB to Henrietta Cook, 1 December 1851, in The Brownings' Correspondence, ed. Philip Kelley, Ronald Hudson, Scott Lewis, and Edward Hagan, 19 vols. (Winfield: Wedgestone Press, 1984-), 17:175.

${ }^{10}$ Browning to Frederick Oldfield Ward, 11 August 1844, in Correspondence, 9:93; author's italics.

${ }^{11}$ John Ruskin to Browning, 2 December 1855, in The Poems of Browning, ed. Daniel Karlin, John Woolford, and Joseph Phelan, 4 vols. (Harlow: Longman, 1991-), 3:734; hereafter cited as Poems.

${ }_{12}$ Browning to Ruskin, 10 December 1855, in Poems, 3:735.

${ }^{13}$ Herbert F. Tucker, Browning's Beginnings: The Art of Disclosure (Minneapolis: University of Minnesota Press, 1980), p. 13.

${ }^{14}$ Browning to EBB, 10 January 1845, in Correspondence 10:17-18.

${ }^{15}$ Browning to EBB, 15 April 1845, in Correspondence, 10:165-6; author's italics.

${ }^{16}$ EBB to Browning, 17 April 1845, in Correspondence, 10:170; author's italics.

${ }^{17}$ Robert Viscusi, “'The Englishman in Italy': Free Trade as a Principle of Aesthetics”, Browning Institute Studies 12 (1984): 25.

${ }^{18}$ These and subsequent line references to Browning's poetry are from Poems.

${ }^{19}$ EBB to Browning, 21 July 1845, in Correspondence, 10:315; author's italics.

${ }^{20}$ Daniel Karlin, Browning's Hatreds (Oxford: Clarendon Press, 1993), p. 246.

${ }^{21}$ Robert Langbaum, The Poetry of Experience: The Dramatic Monologue in Modern Literary Tradition (London: Chatto and Windus, 1957), p. 192.

${ }^{22}$ Huggan also comments that, in uncanny travel writing, the traveller often "joins himself to a confraternity of lost and restless souls", a trope evident, in this monologue, in Roland's preoccupation with the fates of his fellow knights. Graham Huggan, Extreme Pursuits: Travel/Writing in an Age of Globalization (Ann Arbor: University of Michigan Press, 2009), p. 139.

${ }^{23}$ EBB to Isabella Blagden, 8 July 1858, in Florentine Friends: The Letters of Elizabeth Barrett Browning and Robert Browning to Isa Blagden 1850-1861, ed. Philip Kelley and Sandra Donaldson (Winfield: Wedgestone Press, 2009), p. 154.
} 